Vol. I No. 01Hal. $43-47$

15 - Januari 2018

\title{
Hubungan Gaya Kepemimpinan Tutor Dengan Efektifitas Tutorial Berdasarkan Persepsi Mahasiswa/I Fakultas Kedokteran Universitas Batam Tahun 2016
}

\author{
Saiful Batubara
}

Dosen PNS DPK Fakultas Kedokteran UISU

\begin{abstract}
ABSTRAK
Tutorial as the necessary main section for medical study process with KBK. The effective tutorial will bring the student to a certain learning condition with high order thinking in a condusive academic climate. To reach the effectiveness of tutorial, some supporting factors is needed such as, trustworthy between the member of the group, scenario or trigger, student participation and interaction, facilities available, also the tutor role. On PBL the tutor role as the facilitator is to ensure the group discussion's proceed effectively, progressively as well as structurally. Commonly every tutor has it own leadership while proceeding discussion progress that will take effect to student effectiveness on giving opinion. This research is to show the relevance between tutor leadership and tutorial effectivity on student of medical faculty UNIBA academic year 2016. The method for this research is by using observational analytic with cross sectional approach on University Batam Medical Faculy with total sample 184 students and the sampling technique is by simple random sampling. The data analysis is by using Chi-square test. Based on Universitas Batam Medical Faculty student perception, that democratic leadership have a tutorial effectivity by 162 student (88\%), authoritarian leadership have a tutorial effectivity by 8 student $(4,3 \%)$ and freedom leadership have a tutorial effectivity by 11 student $(6 \%)$. Statistic chi-square test result, show p-value by $0,001(p<0,05)$. Based on the research result, it concluded that there is a relevance between tutor leadership and tutorial effectivity based on Universitas Batam Medical Faculty student perception's.
\end{abstract}

\section{PENDAHULUAN}

1. Latar Belakang

Sejak awal tahun 2000 telah dilakukan inisiasi implementasi Kurikulum Berbasis Komptensi $(\mathrm{KBK})$ dalam pendidikan dokter yang diprakarsai oleh beberapa institusi pendidikan seperti Universitas Gajah Mada. Selanjutnya mulai tahun 2002 oleh Direktorat Pendidikan Tinggi Kementerian Pendidikan Nasional melalui proyek HWS/DIKTI dilakukan berbagai pelatihan dan pembinaan dalam rangka implementasi KBK pada semua intitusi pendidikan Dokter di Indonesia mulai tahun 2005. Adapun tujuan dari implementasi KBK tersebut adalah untuk penetapan standar komptensi lulusan pendidikan dokter sesuai dengan standar yang ditetapkan secara nasional. Dalam rangka pencapaian standar kompetensi lulusan dokter di Indonesia, KKI mengeluarkan Standar Pendidikan Profesi Dokter Indonesia (SPPDI). SPDDI menjadi acuan bagi tiap institusi untuk mengembangkan kurikulumnya dan menetapkan metode pembelajaran yang paling sesuai untuk pencapaian kompetensi sesuai dengan paradigma baru pendidikan dokter secara global yang dikenal dengan paradigma SPICES (Student centered, Problem Based Learning, Integrated, Comunity Oriented dan Systematic) yang dikembang oleh Hardem dan digunakan luas dalam pendidikan dokter sejak tahun 1980-an (Konsil Kedokteran Indonesia, 2012). Proses belajar pada kurikulum berbasis penguasaan materi menitikberatkan pada penguasaan kemampuan/keahlian tertentu yang dianggap mampu oleh masyarakat. Dalam implementasinya dalam pendidikan kedokteran dilaksanakan dengan pembelajaran yang berpusat pada mahasiswa dan problem based learning (PBL), dimana pembelajaran utamanya adalah dalam aktivitas pembelajaran kelompok kecil dibawah pengawasan seorang tutor yang berperan sebagai fasilitator yang dikenal dengan istilah kegiatan tutorial. Pentingnya tutorial sebagai bagian utama dalam proses pembelajaran pendidikan dokter dengan KBK sangat menentukan karena proses tutorial yang efektif akan memandu serta memicu mahasiswa melaksanakan pembelajaran mandiri 
atau berkelompok berupa pengumpulan informasi guna dilakukan sintesis untuk menjawab atau menyelesaikan tujuan pembelajaran yang telah ditetapkan dalam proses tutorial dan oleh beberapa ahli pendidikan kedokteran menyebutkan bahwa tutorial merupakan jantungnya PBL (Harsono, 2005). Tutorial yang efektif akan mengantarkan peserta didik pada suatu keadaan pembelajaran dengan pemikiran tingkat tinggi (high order thinking) dalam iklim akademik yang kondusif dengan berlangsungnya pembelajaran yang bersifat kolaboratif baik antara peserta didik maupun dengan pendidik termasuk dalam hal ini tutor. Selain hal tersebut efektif tutorial dapat juga diidentifikasi pada kemampuan menyelesaikan persoalan atau tugas dengan menggunakan berbagai sumber informasi yang tepat dan akurat. Semua kemampuan tersebut secara integratif akan terlihat dalam pencapaian hasil pembelajaran siswa yang diukur secara kuantitatif berupa nilai blok atau modul dan juga indeks prestasi mahasiswa (Akbar, 2014).

Untuk tercapainya keefektifitasan tutorial di butuhkan beberapa faktor yang mendukung seperti, tinggi kepercayaan tentang hubungan di antara anggota-anggota kelompok, skenario atau trigger, interaksi mahasiswa, fasilitas yang tersedia, serta peran tutor. Peran tutor dalam PBL ini menjadi salah satu hal yang menarik banyak para peneliti, karena peran tutor dalam tutorial sangat berbeda dengan peran dosen pada umumnya. Peran tutor dalam PBL berfungsi sebagai fasilitator yang menggunakan keterampilan tertentu untuk membantu individu atau kelompok mencapai suatu tujuan tertentu. Fasilitator bertugas memastikan diskusi kelompok berjalan efektif, baik secara proses maupun secara struktur.

Selain berperan sebagai fasilitator seorang tutor juga harus mempunyai keterampilan agar tutorial dapat berlangsung dengan efektif. Seperti keterampilan bertanya, mendengarkan, merespon, menjelaskan, dan mempersiapkan diri sebelum mengikuti diskusi tutorial. Seorang tutor juga harus memperlukan keterampilan kepemimpinan dalam mengelola proses tutorial. Kepemimpinan yang dimiliki seorang tutor dapat menjadi pedoman dalam memberikan arahan bagi peserta diskusi. Pada saat tutorial biasanya para tutor mempunyai gaya kepemimpinan masing-masing dalam menjalankan proses diskusi yang akan berpengaruh terhadap keefektifitasan para mahasiswa dalam berpendapat. Oleh karena itu setiap tutor memiliki suatu gaya kepemimpinan yang dominan diterapkan. Para tutor biasanya memakai gaya kepemimpinan demokratis dan otoriter pada saat memimpin tutorial. Gaya kepemimpinan demokratis merupakan gaya yang diharapkan pada saat tutorial karena seorang tutor bersedia untuk mendengar, membangun kinerja kelompok, dan pengambilan keputusan berbasis kelompok. Untuk kepemimpinan otoriter sendiri merupakan gaya yang tidak diharapkan karena menyebabkan mahasiswa merasa takut dalam berpendapat dan merasa takut dimarahi oleh tutor (Anggreni, 2012). Berdasarkan penjelasan diatas peneliti tertarik untuk melakukan penelitian tentang Hubungan Gaya kepemimpinan tutor dengan efektifitas tutorial berdasarkan persepsi pada mahasiswa Fakultas Kedokteran Universitas Batam tahun akademik 2016.

\section{Perumusan Masalah}

Gaya kepemimpinan demokratis merupakan gaya yang diharapkan pada saat tutorial karena seorang tutor bersedia untuk mendengar, membangun kinerja kelompok, dan pengambilan keputusan berbasis kelompok. Untuk kepemimpinan otoriter sendiri merupakan gaya yang tidak diharapkan karena menyebabkan mahasiswa merasa takut dalam berpendapat dan merasa takut dimarahi oleh tutor (Anggreni, 2012). 
Saiful Batubara : Hubungan Gaya Kepemimpinan Tutor Dengan Efektifitas Tutorial Berdasarkan Persepsi Mahasiswa/I Fakultas Kedokteran Universitas Batam Tahun 2016.

\section{Tujuan Penelitian}

Untuk mencari hasil dari analisa hubungan gaya kepemimpinan tutor dengan efektifitas tutorial berdasarkan presepsi mahasiswa/i diperoleh bahwa gaya kepemimpinan demokratis dengan efektifitas tutorial yang efektif sebanyak 162 orang (100\%), gaya kepemimpinan otoriter dengan efektifitas tutorial yang efektif sebanyak 8 orang $(88,9 \%)$, dan gaya kepemimpinan bebas dan efektifitas tutorial yang efektif sebanyak 11 orang $(84,6 \%)$. Hasil uji statistik chi-square didapatkan nilai $p=0.00$ lebih kecil dari nilai $\alpha(0,05)$, sehingga dapat disimpulkan Ho ditolak yang artinya ada hubungan yang signifikan antara gaya kepemimpinan tutor dengan efektifitas tutorial berdasarkan presepsi mahasiswa/i Fakultas Kedokteran Universitas Batam Tahun 2016.

\section{Manfaat Penelitian}

Manfaat yang diharapkan sehubungan dengan penelitian ini antara lain :

Bagi Institusi Pendidikan Kedokteran. Hasil penelitian ini diharapkan dapat menjadi acuan untuk menambah wawasan tentang pendidikan kedokteran terutam yang berkaitan dengan proses tutorial dan tutor sebagai tenaga pendidikan utama dalam pengembangan lebih lanjut.

\section{METODE PENELITIAN}

Metode yang digunakan merupakan penelitian observasional analitik dan rancangan penelitian yang digunakan adalah Cross sectional. Penelitian dilakukan di Universitas Batam. Populasi dalam penelitian ini adalah mahasiswa kedokteran di Universitas Batam angkatan 2013 dan 2014. Populasi dalam penelitian ini berjumlah 343 orang. Sampel penelitian sebanyak 184 orang dengan metode pengambilan sampel adalah Random Sampling.

\section{Distribusi Frekuensi Efektivitas Tutorial}

Berdasarkan tabel 4.2 maka dapat diketahui bahwa efektifitas tutorial berdasarkan presepsi mahasiswa sebanyak 181 mahasiswa/i mendapatkan tutorial yang efektif dan sebanyak 3 mahasiswa/i mendapatkan tutorial yang tidak efektif yaitu sebanyak 1 orang dengan gaya kepemimpinan otoriter dan 2 orang dengan gaya kepemimpinan bebas. Sejalan dengan penelitian yang dilakukan oleh Mewo dkk (2016), yang menyatakan bahwa efektifitas kelompok diskusi tutorial Problem Based Learning di Fakultas Kedokteran Universitas Sam Ratulangi umumnya baik dengan hasil yang menunjukkan sebanyak 38 mahasiswa/i memiliki tutorial yang efektif dan 2 mahasiswa/i yang memiliki tutorial yang tidak efektif. Berdasarkan analisis data dan pengamatan langsung oleh peneliti saat tutorial bahwa hal ini bisa terjadi karena mahasiswa/i berperan aktif dalam melaksanakan jalannya tutorial, semakin aktif mahasiswa melaksanakan proses tutorial yang artinya seluruh mahasiswa/i kritis dalam mengemukakan pendapat atau opininya namun tidak keluar dari jalur bahasan utama tutorial tersebut, yang diam didorong berpendapat dan yang dominan diminta untuk mengurangi dominasinya, selain itu saling menghormati pendapat sesama peserta tutorial maka jalanannya tutorial semakin kooperatif dan efektif. Hal lain yang bisa membuat tutorial menjadi efektif yaitu dari sisi fasilitatornya, dimana fasilitator tersebut tidak membuat mahasiswa/i merasa tertekan atau takut untuk berpendapat. Sejalan dengan teori yang dikemukakan oleh Sefton (2005) bahwa tutorial yang efektif adalah seluruh anggota kelompok berpartisipasi aktif dalam proses tutorial, seluruh anggota kelompok saling menghormati pendapat anggota kelompok, tetapi tetap bersikap kritis dan setiap anggota kelompok dibantu untuk tidak mengalami stres personal atau tekanan. 
Saiful Batubara : Hubungan Gaya Kepemimpinan Tutor Dengan Efektifitas Tutorial Berdasarkan Persepsi Mahasiswa/I Fakultas Kedokteran Universitas Batam Tahun 2016.

\section{Hubungan Gaya Kepemimpinan Tutor Dengan Efektifitas Tutorial Berdasarkan Presepsi Mahasiswa/i Fakultas Kedokteran Universitas Batam}

Berdasarkan hasil analisa hubungan gaya kepemimpinan tutor dengan efektifitas tutorial berdasarkan presepsi mahasiswa/i diperoleh bahwa gaya kepemimpinan demokratis dengan efektifitas tutorial yang efektif sebanyak 162 orang (100\%), gaya kepemimpinan otoriter dengan efektifitas tutorial yang efektif sebanyak 8 orang $(88,9 \%)$, dan gaya kepemimpinan bebas dan efektifitas tutorial yang efektif sebanyak 11 orang $(84,6 \%)$. Hasil uji statistik chi-square didapatkan nilai $\mathrm{p}=0.00$ lebih kecil dari nilai $\alpha(0,05)$, sehingga dapat disimpulkan Ho ditolak yang artinya ada hubungan yang signifikan antara gaya kepemimpinan tutor dengan efektifitas tutorial berdasarkan presepsi mahasiswa/i Fakultas Kedokteran Universitas Batam Tahun 2016.

\section{KESIMPULAN DAN SARAN}

\section{Kesimpulan}

Berdasarkan dari hasil penelitian ini dapat disimpulkan bahwa gaya kepemimpinan berpengaruh dalam jalannya tutorial yang efektif, biasanya para tutor mempunyai gaya kepemimpinan masing-masing dalam menjalankan proses diskusi yang akan berpengaruh terhadap keefektifitasan para mahasiswa dalam berpendapat. Gaya kemimpinan yang sesuai dengan kehendak mahasiswa/i adalah yang berusaha menjalankan diskusi lebih partisipatif, bersedia untuk mendengar, menengahi perbedaan pendapat, pengambilan keputusan berbasis kelompok, membangun kinerja kelompok sehingga keefektifitasan tutorial bisa tercapai. Dikatakan tutorial yang efektif apabila mahasiswa/i berperan aktif dalam melaksanakan jalannya tutorial, kritis dalam mengemukakan pendapat atau opininya namun tidak keluar dari jalur bahasan utama tutorial tersebut, dan saling menghormati pendapat sesama peserta tutorial maka jalanannya tutorial semakin kooperatif serta efektif. Hal ini sejalan dengan teori yang dikemukakan oleh (Schwarz, 2008), dimana seorang fasilitator bertugas memastikan diskusi kelompok berjalan efektif secara proses maupun secara struktur. Efektif secara proses maksudnya kelompok dapat bekerja sama dalam mencapai tujuan tertentu, sedangkan efektif secara struktur maksudnya setiap anggota mampu menjalankan perannya masing-masing sehingga menciptakan.

1. Sebanyak 162 responden (88\%) mahasiswa FK UNIBA angkatan 2013 dan 2014 lebih menginginkan gaya demokratis sebagai gaya kepemimpinan fasilitator.

2. Mahasiswa/i Fakultas Kedokteran angkatan 2013 dan 2014 mempersepsi proses tutorial efektif itu sebesar 181 orang $(98.4 \%)$.

3. Terdapat hubungan yang sangat signifikan antara gaya kepemimpinan tutor dengan efektifitas tutorial dengan $\mathrm{p}=0,00$

\section{Saran}

1. Bagi Institusi Pendidikan Kedokteran.

Hasil penelitian ini diharapkan dapat menjadi acuan untuk menambah wawasan tentang pendidikan kedokteran terutam yang berkaitan dengan proses tutorial dan tutor sebagai tenaga pendidikan utama dalam

2. Bagi Mahasiswa.

Mahasiswa diharapkan lebih meningkatkan pengetahuan mengenai gaya kepemimpinan tutor, sehingga mahasiswa dapat melakukan kegiatan tutorial secara efektif.

3. Bagi Peneliti Lain 
Saiful Batubara : Hubungan Gaya Kepemimpinan Tutor Dengan Efektifitas Tutorial Berdasarkan Persepsi Mahasiswa/I Fakultas Kedokteran Universitas Batam Tahun 2016.

Hasil penelitian ini diharapkan dapat dimanfaatkan sebagai bahan referensi penelitian yang sejenis.

\section{DAFTAR PUSTAKA}

Akbar Surya, Anggreni Siska.2014. Problem Based Learning. Bandung: Citapustaka Media.

Arifin Syamsul. 2012. Ilmu dan Seni Kepemimpinan. Jakarta: Mitra Wacana Media.

Agus Riyanto. 2011. Metodologi Penelitian Kesehatan. Yogyakarta: Nuha Medika

Anggraeni, Siska. 2012. Penilaian Mahasiswa Dan Pemahaman Fasilitator Mengenai Tipe Kepemimpinan Fasilitator Dalam Diskusi Kelompok Tutorial PBL Di FK UISU. Jakarta. Universitas Indonesia.

Thesis Batubara et al. 2012. Pendidikan Kedokteran Kontemporer. Medan: Perdana Publishing

Dorman et al. 2000. Problem are the key Feature of problem Based Learning. United Kingdom: Departement of edicational Development and Research Mastricht.

Dornan T, Mann K. 2011. MedicalEducation Theory and Practice. Edinburgh: Churcill Livingstone Elsivier.

Dwiloka Bambang. 2005. Teknik Menulis Karya Ilmiah. Jakarta: PT Rineka Cipta.

Edmunds S, Brown G. 2010. Effective small group learning. USA: Amee Guide

Fahmi Irfan. 2011. Manajemen Kepemimpinan. Bandung: Alfabeta

Halonen D. 2010. Problem Based Learning: A case study. Canada: University of Manitoba

Harsono Dwiyanto. 2005.Pembelajaran Berpusat Mahasiswa. Yogyakarta: Riset

Latukonsina Vina Z. 2012. Evaluasi Diri Problem Based Learning (PBL) Pada Blok Biomedik 5 Mahasiswa Semester 2 Fakultas Kedokteran Universitas Pattimura. Jurnal Kedokteran dan Kesehatan, 5(1):pp 24-31 http://ejournal.unpatti.ac.id diakses pada bulan Juni 2016.

Lubis Siska Anggreni. 2013. Penilaian Mahasiswa dan Pemahaman Fasilitator Mengenai Tipe Kepemimpinan Fasilitator Dalam Diskusi Kelompok Tutorial PBL Di FK UISU. Jakarta, Universitas Indonesia. Thesis

Notoatmodjo Soekidjo. 2010. Metodologi Penelitian. Jakarta: PT Rineka Cipta.

Mc Kim J, Swanwick T. 2010. Educational leadersip in understanding medical education. Blackwell publishing : John Wiley \& Sons

Mewo, dkk. 2016. Efektivitas Kelompok Diskusi Tutorial Problem Based Learning di Fakultas Kedokteran Universitas Sam Ratulangi. e-Biomedik, vol 4 no 1. 